\title{
A novel mechanism underlies atrazine toxicity in quails (Coturnix Coturnix coturnix): triggering ionic disorder via disruption of ATPases
}

\author{
Jia Lin ${ }^{1, *}$, Hui-Xin Li ${ }^{2, *}$, Lei Qin ${ }^{1,3, *}$, Zheng-Hai Du ${ }^{1}$, Jun Xia ${ }^{1}$ and Jin-Long Li ${ }^{1}$ \\ ${ }^{1}$ College of Veterinary Medicine, Northeast Agricultural University, Harbin, People's Republic of China \\ 2 Division of Avian Infectious Diseases, State Key Laboratory of Veterinary Biotechnology, Harbin Veterinary Research \\ Institute, Chinese Academy of Agricultural Sciences, Harbin, People's Republic of China \\ ${ }^{3}$ Laboratory Animal Centre, Qiqihar Medical University, Qiqihar, People's Republic of China \\ ${ }^{*}$ These authors have contributed equally to this study \\ Correspondence to: Jin-Long Li, email: Jinlongli@neau.edu.cn \\ Keywords: atrazine, ionic disorder, ATPases, heart and liver, Pathology Section \\ Received: September 01,2016 Accepted: November 22,2016 Published: December 04, 2016
}

\section{ABSTRACT}

The widely used atrazine has been reported to exhibit extensive ecological hazards. Due to the biological accumulation, atrazine elicits widespread toxic effects on different organisms. However, true proof for the mechanism of atrazine-induced toxicity is lacking. To determine the potential mechanism by which atrazine exerted toxic effects, quails were treated with atrazine $(0,50,250$ and $500 \mathrm{mg} / \mathrm{kg})$ by gavage administration for $\mathbf{4 5}$ days. Atrazine significantly increased the histological alterations and serum creatine kinase, lactate dehydrogenase and choline esterase levels. A marked disorder in ionic $\left(\mathrm{Na}^{+}, \mathrm{K}^{+}, \mathrm{Ca}^{2+}\right.$ and $\left.\mathrm{Mg}^{2+}\right)$ contents and the decrease of ATPases ( $\mathrm{Na}^{+}-\mathrm{K}^{+}$-ATPase, $\mathrm{Ca}^{2+}$-ATPase, $\mathrm{Mg}^{2+}$-ATPase and $\mathrm{Ca}^{2+}-\mathrm{Mg}^{2+}-$ ATPase) activities were observed in the heart and liver of atrazine-exposed quails. Of note, it was also observed that atrazine suppressed the transcription of $\mathrm{Na}^{+}, \mathrm{K}^{+}$transfer associated genes ( $\mathrm{Na}^{+}-\mathrm{K}^{+}$-ATPase subunits) and $\mathrm{Ca}^{2+}$ transfer associated genes (Ca ${ }^{2+}-\mathrm{ATPase}$ subunits, solute carriers) in heart and liver. In conclusion, atrazine induced cardiac and hepatic damage via causing the ionic disorder, triggering the transcription of the ion transporters and leading the histopathological and functional alternations in the heart and liver of quails. This study demonstrated atrazine significantly induced the ionic disorder via decreasing the ATPases activities and disturbing the transcription of the ion transporters.

\section{INTRODUCTION}

The most commonly used herbicide, atrazine, has been extensively monitored in the whole world, contaminating plants, soil, water resources $[1,2]$. Atrazine, with a half-life of 30-740 days [3], is very stable in the environment due to little loss by volatilization, low sediment partitioning, and relatively slow rates of degradation [4].Of note, due to its biological accumulation effect, atrazine do a great harm to the health of organisms and human $[5,6]$. Atrazine exposure at environmentally relevant doses or below resulted in endocrine disruptive effects, clear immunomodulatory, genotoxic action, metabolic disorders, neurodegenerative disorders, and so on [7-11]. Recent results from our laboratories clearly demonstrated that atrazine-induced developmental abnormality of ovary and oviduct is associated with disruption of gonadal hormone balance and hypothalamopituitary-ovarian axis in quails [12]. Atrazine induced hepatotoxicity and cardiotoxicity in aquatics and mammals [13-18]. Knowledge on the mechanism of these critical organs in toxicological responses to atrazine in increasing, however, has not been completely elucidated.

Numerous studies have demonstrated that exposure to atrazine induced oxidative stress, lipid peroxidation and antioxidant depletion [19-26]. In addition, it was found that atrazine exposure caused changes in erythrocytes membranes, DNA damage, mitochondrial dysfunction, 
Table 1: Animal groups

\begin{tabular}{|c|c|c|c|}
\hline Groups & Number & Drug & Concentration \\
\hline Con (Control) & 50 & Pure water & 0 \\
\hline LD (Low-dose atrazine) & 50 & Atrazine & $50 \mathrm{mg} / \mathrm{kg}$ \\
\hline MD (Middle-dose atrazine) & 50 & Atrazine & $250 \mathrm{mg} / \mathrm{kg}$ \\
\hline HD (High-dose atrazine) & 50 & Atrazine & $500 \mathrm{mg} / \mathrm{kg}$ \\
\hline
\end{tabular}

cell autophagy and apoptosis [22, 25-29]. In our previous studies, atrazine is known to disturb ionic balance in mice liver and heart $[18,30]$, but less is known in birds.

Proper ion concentrations are benefit for a number of physiological processes such as transmembrane ionic balance, membrane potential, $\mathrm{pH}$ balance and cell volume to ensure correct functions of the entire body, especially the heart and liver [31]. Indeed, abnormal ion concentrations, indicating a water-electrolyte imbalance, may be partially responsible for arrhythmias, muscle contraction disorders or the incidence of death resulting from cardiovascular events [18, 32-34]. Heart and liver have been identified as the organs for atrazine-induced ionic disorders $[18,30]$. However, it remains to be determined whether the effect of atrazine on the ionic imbalance contributes to organ dysfunction in birds.

Considering the central role in whole-body osmoregulation and high susceptibility to atrazine attack, ATPase is widely used as a marker for ion regulatory changes $[35,36]$. In addition, ATPases are a group of membrane-bound enzymes responsible for transporting the cations across the cell membrane, maintaining intracellular functions [37, 38]. Although it is reported the effects of atrazine on ionic disorder and ATPases disturbance in mice, the data concerning the birds were limited. Therefore, the aim of our study was to investigate the deleterious effects of atrazine on the heart and liver of quails, the involvement of the ionic disorder, and the possible mechanism of atrazine-induced organs damage.

\section{RESULTS}

\section{Effects of atrazine on heart/liver weight and biochemical parameters analyses in quails}

The animals in groups all remained relatively in good health throughout the study and there were no exposure-related clinical observations. Furthermore, atrazine had no effect on feed intake or body weights in male quails. Interestingly, we found that the heart coefficient decreased $(P<0.05)$ in quails of HD group and the liver coefficient increased $(P<0.05, P<0.05, P<0.05)$ in all atrazine-exposed quails, respectively (Figure 1a).

\section{Effects of atrazine on the biochemical and histopathological analyses}

Regarding the biochemical analyses, the serum LDH was significantly pronounced upon decrease by atrazine at LD group $(P<0.05$; Figure $1 b)$. We also checked that serum LDH and CK levels were increased after treat with atrazine at HD group $(p<0.001, p<0.01$; Figure $1 b)$, as LDH and CK had been suggested to impact the function of heart. We then detected CHE and GGT in serum. No difference in serum GGT was observed between Con and atrazine-exposed groups (Figure 1c). Additionally, serum CHE was found to increasingly evident with dosage of atrazine (Figure 1c), especially in MD and HD groups $(P<$ $0.01, P<0.001)$, suggesting an injury in atrazine-exposed quail liver.

In order to investigate the effect of atrazine in organ injury, we conducted histological analysis of heart and liver sections, which measured the degree of organ injury. Cardiomyocytes of atrazine-exposed quails exhibit an increase in the number of nuclear vacuoles, especially marked promotion of nuclear vacuoles in MD and HD groups (Figure 1d). Myocardial fiber dissolution or fracture can be found in HD group (Figure 1d). Swelling of cardiac myocytes was observed in LD group (Figure 1d). Analyzing microanatomy alterations in hepatocytes, we found hyperaemia in central vein and hepatic sinusoid with dose-related increases (Figure 1e). The hepatocyte swollen became more serious as the dose of atrazine increases (Figure 1e). In addition, the derangement of hepatic plate aggravated gradually with the dosage increasing (Figure 1e) was observed in atrazine-exposed quails.

\section{Detection of $\mathrm{Na}^{+}, \mathrm{K}^{+}$content, $\mathrm{Na}^{+}-\mathrm{K}^{+}$-ATPase activity and ATPase subunit transcription}

To investigate the effects of $\mathrm{Na}^{+}-\mathrm{K}^{+}$-ATPase on $\mathrm{Na}^{+}, \mathrm{K}^{+}$disorder directly in heart and liver, we tested $\mathrm{Na}^{+}, \mathrm{K}^{+}$content, $\mathrm{Na}^{+}-\mathrm{K}^{+}$-ATPase activity and ATPase subunit transcription. $\mathrm{K}^{+}$content was deeply suppressed by atrazine in the heart, liver and serum, as compared with Con group (Figure $2 \mathrm{a}$ ). $\mathrm{Na}^{+}$content was significantly increased in the heart and liver in HD group $(p<0.01$, $p<0.001$ ), the serum $\mathrm{Na}^{+}$didn't show any difference in groups (Figure 2a). Similar to function of serum $\mathrm{Na}^{+}$, serum $\mathrm{Cl}^{-}$help to maintain the electrolyte homeostasis, 
acid-base equilibrium and osmotic balance. However, we did not observe changes in serum $\mathrm{Cl}^{-}$(Figure $\mathrm{S} 1$ ). The activities of cardiac and hepatic $\mathrm{Na}^{+}-\mathrm{K}^{+}$-ATPase in the atrazine-treated groups were shown in Figure $2 \mathrm{~b}$. The $\mathrm{Na}^{+}-\mathrm{K}^{+}$-ATPase activities in the atrazine-treated groups significantly decreased $(P<0.001)$ in all atrazine treated groups compared to Con group on heart and liver. The maximal adverse effects were observed for cardiac and hepatic $\mathrm{Na}^{+}-\mathrm{K}^{+}$-ATPase activities after the administration of $500 \mathrm{mg} / \mathrm{kg}$ atrazine $(P<0.01)$.

Since transcription of $\mathrm{Na}^{+}-\mathrm{K}^{+}$-ATPase can alter the activity of $\mathrm{Na}^{+}-\mathrm{K}^{+}$-ATPase, we next detected the expression of $\mathrm{Na}^{+}-\mathrm{K}^{+}$-ATPase associated subunits transcription. These results revealed a set of $\mathrm{Na}^{+}-\mathrm{K}^{+}$-ATPase subunits (1a1, 1b3) in quail heart whose transcription was first increased in LD and then decreased in MD and HD significantly by atrazine treatment, compared to Con group. Additionally, a set of $\mathrm{Na}^{+}-\mathrm{K}^{+}$-ATPase subunits $(1 \mathrm{a} 2,1 \mathrm{a} 3,1 \mathrm{~b} 4)$ genes was decreased by atrazine in heart, compared to Con group $(P$ $<0.001$ ) (Figure 2c; Figure S2a). Inspection of the results of atrazine-induced genes transcription alterations in liver and heart appeared to have a similar, albeit more variable, effect. In the liver, a set of $\mathrm{Na}^{+}-\mathrm{K}^{+}$-ATPase subunits (1a2, 1b3) was first increased in LD and then decreased markedly in HD. A set of $\mathrm{Na}^{+}-\mathrm{K}^{+}$-ATPase subunits (1a2, 1a3) in quail liver was decreased induced by atrazine treatment (Figure 2c; Figure S2b). The effects of atrazineinduced $\mathrm{Na}^{+}-\mathrm{K}^{+}$-ATPase activity down-regulating were likely due to lower expression levels of the transcription of $\mathrm{Na}^{+}-\mathrm{K}^{+}$-ATPase associated subunits (Figure 2b, c; Figure a

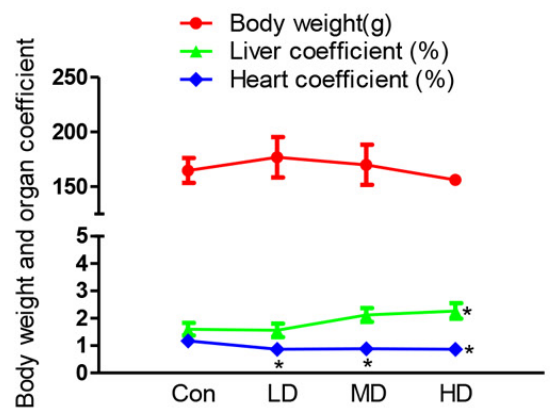

b

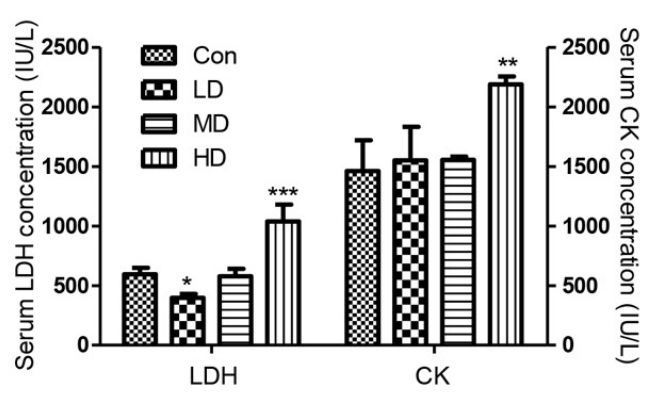

C

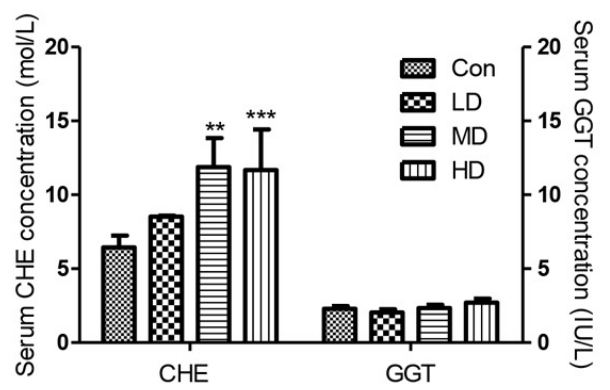



Figure 1: Effects of atrazine on the organ coefficient, biochemical analysis and histopathological in quail heart and liver. a. Body weight and organ coefficient; b. The LDH and CK activity in serum; c. The CHE and GGT activity in serum; d. The histopathological analysis in heart; e. The histopathological analysis in liver. The magnification of the microscope is $40 \times 10$ times the original size, and the arrows in white point to the location of the lesion. Values were expressed as mean \pm S.D.. Symbol for the significance of differences between the vehicle control and another: ${ }^{*} P<0.05, * * P<0.01,{ }^{* * *} P<0.001$. 
S2).

\section{Detection of $\mathrm{Ca}^{2+}$ content, $\mathrm{Ca}^{2+}$-ATPase} activity and $\mathrm{Ca}^{2+}$ transport associated subunits transcription

To address the role of $\mathrm{Ca}^{2+}$ disorder in organ injury, we tested not only $\mathrm{Ca}^{2+}$ content, $\mathrm{Ca}^{2+}$-ATPase activity and ATPase subunits transcription, but also calpain, the $\mathrm{Na}^{+} /$ $\mathrm{Ca}^{2+}$ exchangers (NCXs) and the $\mathrm{Na}^{+} / \mathrm{Ca}^{2+}-\mathrm{K}^{+}$exchangers (NCKXs) associated subunits gene transcription in heart

\section{a}
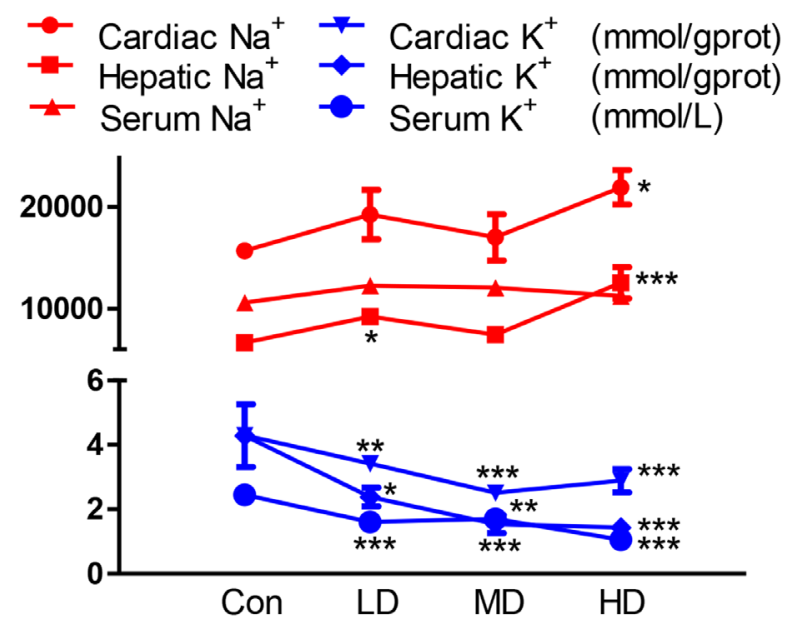

C


and liver. The cardiac $\mathrm{Ca}^{2+}$ content was significantly increased in LD, MD and HD groups $(P<0.001, P$ $<0.001, P<0.005)$. Similar to alterations in heart, the hepatic $\mathrm{Ca}^{2+}$ content was significantly increased in LD and MD groups $(P<0.001, P<0.005)$. However, we also observed that there were no significant alterations in serum $\mathrm{Ca}^{2+}$ of atrazine-exposed quails (Figure 3a). Moreover, the activities of $\mathrm{Ca}^{2+}$-ATPase in heart and liver of atrazinetreated quails were significantly decreased $(P<0.001)$ in all atrazine treated groups (Figure $3 b$ ).

A heat map showed the expressions of the $3 \mathrm{Ca}^{2+}$ ATPase subunits, calpain and solute carriers (SLCs) in

\section{b $\quad \mathrm{Na}^{+}-\mathrm{K}^{+}$ATPase}
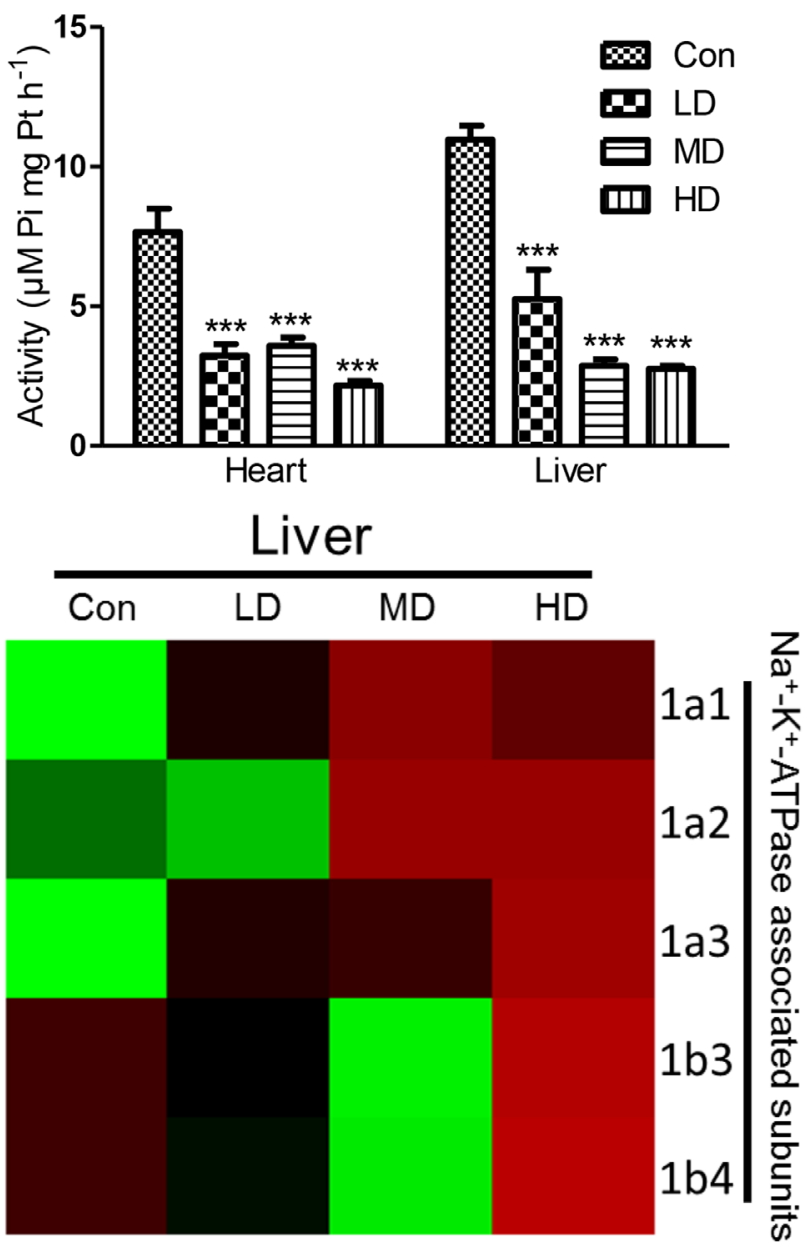

Scale:

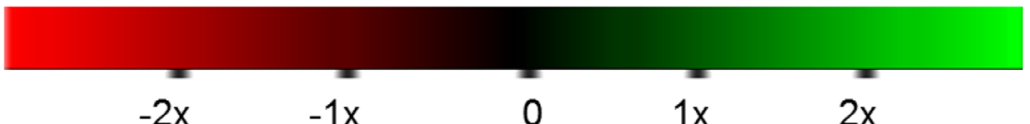

Figure 2: Effects of atrazine on the modulation of $\mathbf{K}^{+}$transfer channel. a. The $\mathrm{Na}^{+}, \mathrm{K}^{+}$content in heart, liver and serum; $\mathbf{b}$. The $\mathrm{Na}^{+}-\mathrm{K}^{+}$-ATPase activity in heart and liver; c. The heat-map of $\mathrm{Na}^{+}-\mathrm{K}^{+}$-ATPase associated subunits in heart and liver. Values were expressed as mean \pm S.D. Symbol for the significance of differences between the vehicle control and another: $* P<0.05, * * P<0.01, * * * P<0.001$. The mRNA expression levels of genes transcription are shown using the indicated pseudo color scale from $-2 \mathrm{x}$ (green) to $+2 \mathrm{x}$ (red) relative to values for Con group. The color scale represents the relative mRNA expression levels, with green indicating up-regulated genes, red indicating down-regulated genes, and black indicating unchanged genes. 
atrazine-treated quails (Figure $3 \mathrm{c}$ ). These results revealed that the expression of $\mathrm{Ca}^{2+}$-ATPase subunit $2 \mathrm{a} 1$ in heart decreased in MD and HD groups (Figure 3c), compared to Con group $(P<0.01, P<0.001)$ (Figure S3a). Another set of genes $(2 \mathrm{a} 2,2 \mathrm{a} 3)$ in heart was first increased in LD group and then decreased in HD group (Figure 3c), compared to Con group $(P<0.05)$ (Figure S3a). Similar to the alterations in heart, a set of $\mathrm{Ca}^{2+}$-ATPase subunits (2a1, 2a3) expression was markedly decreased in MD and HD groups (Figure 3c), compared to Con group $(P<0.001$, $P<0.001)$ (Figure $\mathrm{S} 3 \mathrm{~b}$ ). The expression of $\mathrm{Ca}^{2+}$-ATPase subunit $2 \mathrm{a} 2$ in quail liver was first increased in LD and then decreased in HD group (Figure 3c), compared to Con group $(P<0.001, P<0.05)$ (Figure $\mathrm{S} 3 \mathrm{~b})$. Moreover, we observed that expression of calpain in heart was significantly increased in LD group $(P<0.001)$ (Fig $3 \mathrm{c}$; Figure S3c). The hepatic calpain transcription was significantly increased in MD and HD groups $(P<0.01, P$ $<0.001$; Figure 3c; Figure S3d).

The NCXs form the SLC8 family, with NCX1, NCX2 and NCX3 being coded for by the genes SLC8A1, SLC8A2 and SLC8A3 respectively $[39,40]$. The NCKXs form the SLC24 family, with the five members being coded for by the genes SLC24A1- SLC24A5 and some splice variants exist [41]. The expressions of the SLCs (SLC8A1-3, SLC8B1, SLC24A1-2) in liver and heart were tested in this experiment. Almost all of the SLCs in heart were significantly suppressed in HD group (Figure $\mathrm{S} 3 \mathrm{e})$. However, SLC8A1 and SLC8A2 in liver were significantly enhanced in $\mathrm{MD}$ and $\mathrm{HD}$ groups (Figure S3f), and SLC8A3, SLC8B1, SLC24A1, SLC24A2 were significantly decreased in HD group (Figure S3f).

\section{Detection of $\mathrm{Mg}^{2+}$ content and the activities of $\mathrm{Mg}^{2+}$-ATPase and $\mathrm{Ca}^{2+}-\mathrm{Mg}^{2+}$-ATPase}

Cardiac $\mathrm{Mg}^{2+}$ content showed a significant decrease in LD and HD groups compared to Con group $(P<0.01$; Figure 4a). However, hepatic $\mathrm{Mg}^{2+}$ content showed no significant alteration in atrazine-exposed groups compared to Con group (Figure 4a). The serum $\mathrm{Mg}^{2+}$ content showed a significant increase in atrazine-exposed groups compared to Con group ( $P<0.01, P<0.01, P<0.001$; Figure 4a). a
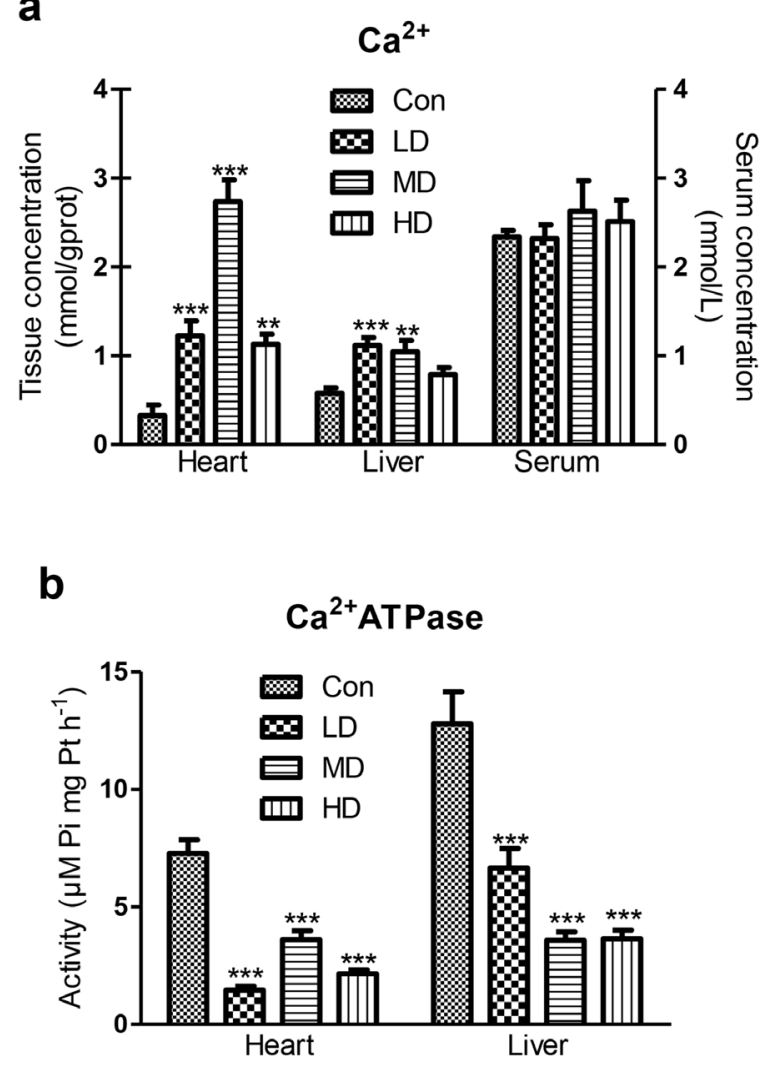

C
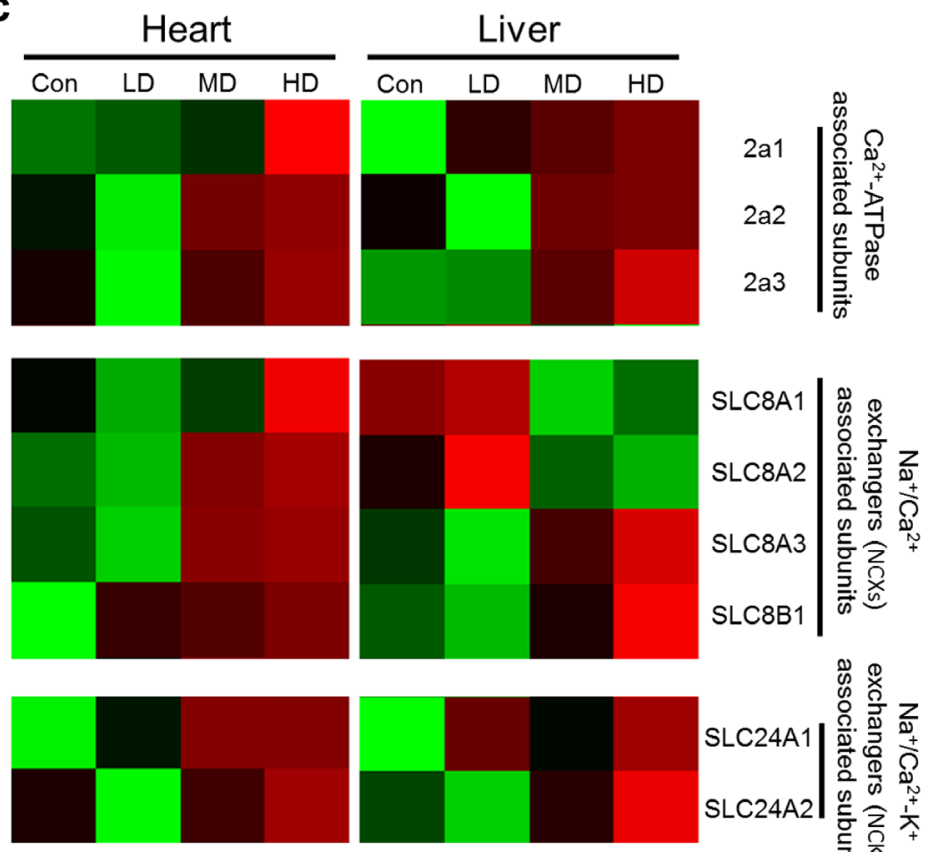

SLC24A1


Calpain

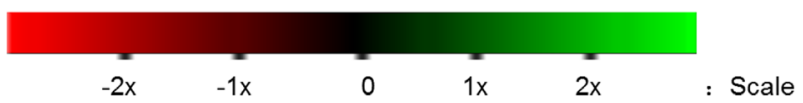

Figure 3: Effects of atrazine on the modulation of $\mathbf{C a}^{2+}$ transfer channel. a. The $\mathrm{Ca}^{2+}$ content in heart, liver and serum; $\mathbf{b}$. The $\mathrm{Ca}^{2+}$-ATPase activity in heart and liver; $\mathbf{c}$. The heat-map of $\mathrm{Ca}^{2+}$-ATPase associated subunits, calpain and SLCs. Values were expressed as mean \pm S.D.. Symbol for the significance of differences between the vehicle control and another: $* P<0.05, * * P<0.01, * * * P<0.001$. The mRNA expression levels of genes transcription are shown using the indicated pseudo color scale from $-2 x$ (green) to $+2 x$ (red) relative to values for Con group. The color scale represents the relative mRNA expression levels, with green indicating up-regulated genes, red indicating down-regulated genes, and black indicating unchanged genes. 
The $\mathrm{Ca}^{2+} / \mathrm{Mg}^{2+}$ ratio was significant increase in heart at all atrazine treated groups $(P<0.001$; Figure $4 \mathrm{~b})$ and in liverat LD and MD groups $(P<0.01, P<0.05$; Figure $4 \mathrm{~b})$; however, the $\mathrm{Ca}^{2+} / \mathrm{Mg}^{2+}$ ratio was significant decrease in serum $(P<0.01, P<0.01, P<0.001$; Figure $4 \mathrm{~b})$.

Figure $4 \mathrm{c}$ showed a significant decrease in cardiac $\mathrm{Mg}^{2+}$-ATPase activity in atrazine-exposed groups compared to Con group $(P<0.001, P<0.001, P<$ $0.001)$. Similar to the alterations in heart, a significant decrease in hepatic $\mathrm{Mg}^{2+}$-ATPase activity in atrazineexposed groups $(P<0.05, P<0.001, P<0.001)$ was also observed. The results of $\mathrm{Ca}^{2+}-\mathrm{Mg}^{2+}$-ATPase activity after atrazine exposure were presented in Figure $4 \mathrm{~d}$. There was a significant decrease on $\mathrm{Ca}^{2+}-\mathrm{Mg}^{2+}$-ATPase activity of atrazine-exposed groups compared to Con group $(P<$ $0.001, P<0.001, P<0.001)$ in heart and liver. These data, in light of previous reports including ours $[18,30]$ stating that atrazine-induced $\mathrm{Mg}^{2+}$ disorder was increased by disturbing the activities of $\mathrm{Mg}^{2+}$-ATPase and $\mathrm{Ca}^{2+}-\mathrm{Mg}^{2+}-$ ATPase.

\section{PCA of cardiac and hepatic ionic homeostatic modulation}

PCA for the relevant metabolites was performed with an analysis of variance $(P<0.05)$, and the results were depicted in Figure 5. PC1, PC2 and PC3 conglomerated more than $80 \%$ of the total variance (Table S2). Cross-validation allowed checking of the predictive power of the generated model using the Q2/R2 ratio as a measure of the reliability of the predictions. This ratio was above 0.8 for PC1, PC2 and PC 3 , suggesting that the generated model was consistent and valid (Table S2).

To distinguish potential effects of biochemical parameters in quails receiving different doses of atrazine, PCA was performed as an unsupervised pattern recognition method. The PCA scores showed that the doserelated separation within the atrazine-treated animals was quite remarkable in both heart and liver, and the changes in metabolic profiles from the controls to the low- middleand high-dose groups occurred in a clockwise direction;
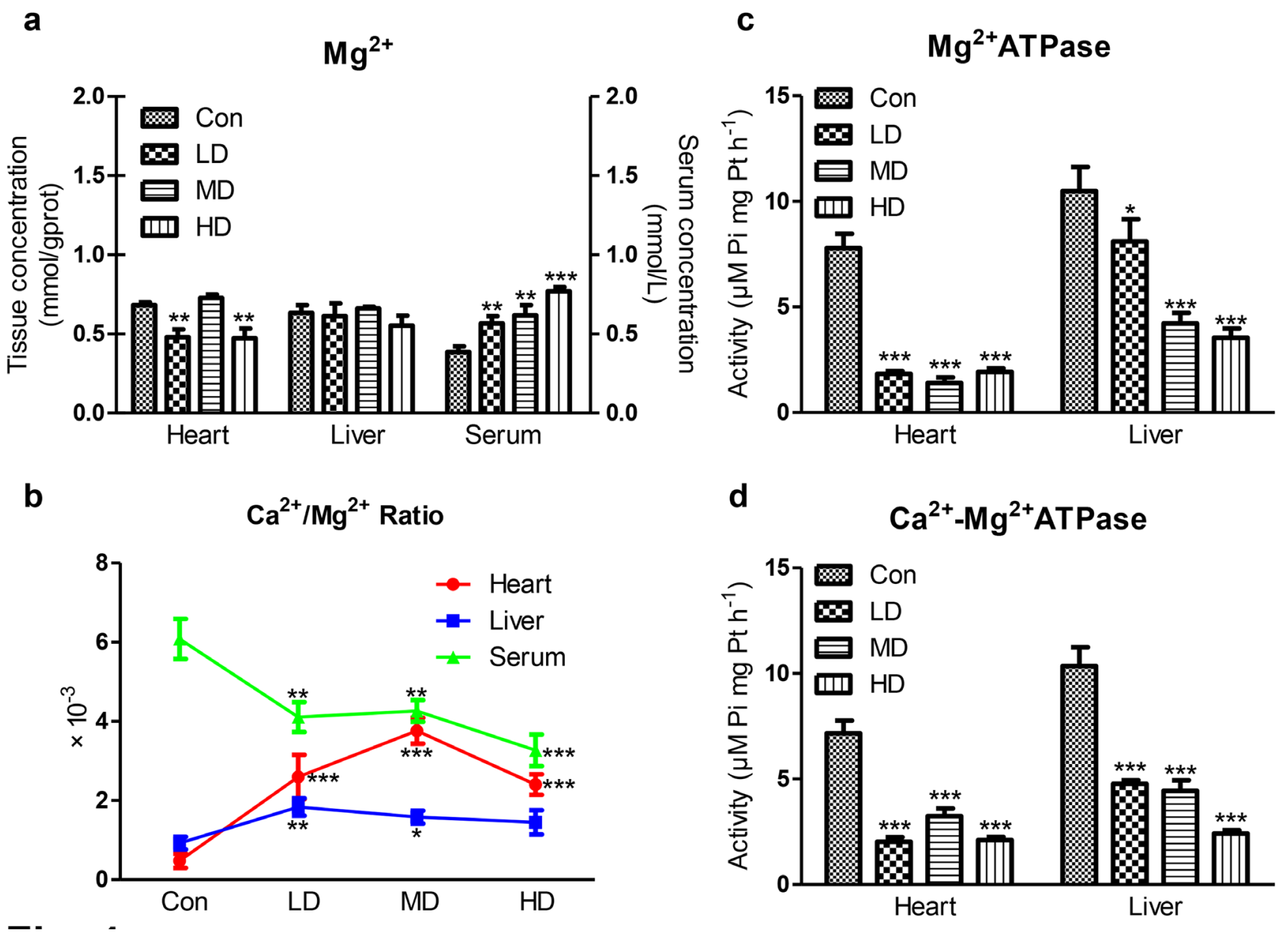

Figure 4: Effects of atrazine on the modulation of $\mathrm{Mg}^{2+}$ transfer channel. a. The $\mathrm{Mg}^{2+}$ content in heart, liver and serum; $\mathbf{b}$. The $\mathrm{Ca}^{2+} / \mathrm{Mg}^{2+}$ ratio in quail heart, liver and serum; c. The $\mathrm{Mg}^{2+}$-ATPase activity in heart and liver; $\mathbf{d}$. The $\mathrm{Ca}^{2+}-\mathrm{Mg}^{2+}$-ATPase activity in heart and liver. Values were expressed as mean \pm S.D.. Symbol for the significance of differences between the vehicle control and another: $* P$ $<0.05, * * P<0.01, * * * P<0.001$. 
while clearly separated from the controls (Figure 5). Taken together, these results showed that atrazine exposure resulted in dose-related changes in biochemical parameters in both heart and liver.

\section{DISCUSSION}

Atrazine can interfere with the normal operation of the cardiovascular system leading to a broad range of disorders, increased rates of cardiovascular diseases $[18,42]$. Liver is viewed as a primary organ for atrazine metabolism, which is known to cause hepatic damage in mammalian $[15,43,44]$. However, whether the effects of atrazine have the potential influence to the cardiac and hepatic function of birds still remain unclear. The quail is increasingly used as a model species for studies of stress physiology including the effects of the exposure to environmental chemicals such as atrazine. Of note, our findings are in accordance with previous studies $[18,30]$ that showed atrazine induced cardiotoxicity and hepatotoxicity in mice via the disturbance of ionic balance, but molecular disease mechanisms remain to be elucidated in birds.

Atrazine had been reported to interfere the growth and development of quails, to disturb its reproductive function, to induce endocrine disruption and to trigger the pathological and genotoxic effects $[7,11,45]$. In the present study, nomortality occurred at any dose of ATR administered. There were no consistent effects of ATR on body weight and clinical behavior alterations on female [12] and male quails, which might be attributable to the effects of ATR on sexual organs damage in different pathways.

In this study, significantly ionic disorders and

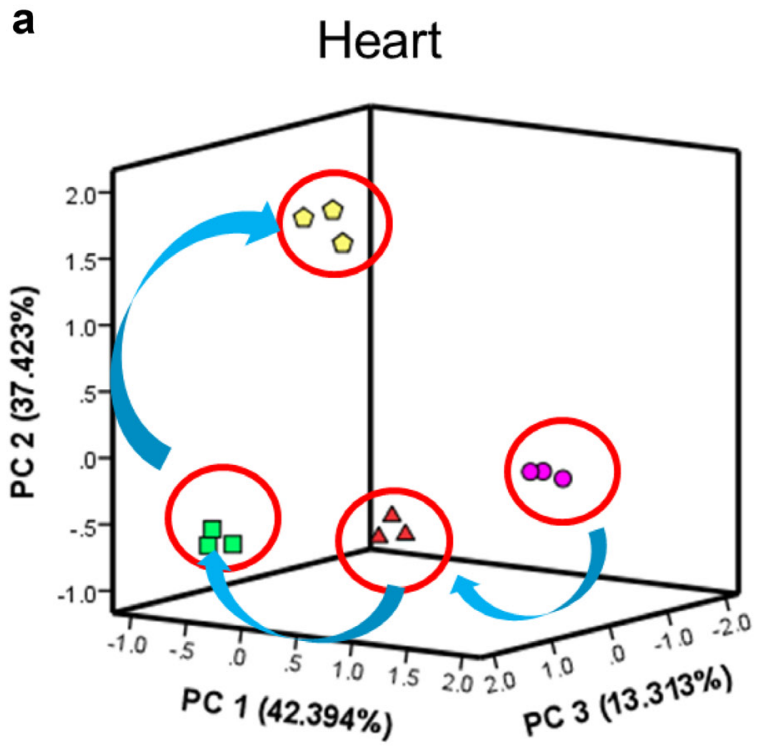

organs injury were observed in the liver and heart of quails. According to previous studies, atrazine can induce pathological effects in multiple tissues $[7,12]$. Atrazine was recorded in the liver and heart [46-49], suggesting the heart and liver are organs involved in the metabolism of atrazine. Our previous study showed that atrazine induced significantly ionic disorder in the liver and heart on mice as well $[18,30]$. Therefore, the liver and heart have been identified as the organs for atrazine-induced ionic disorders. In accordance with our findings in quails, atrazine stimulated ionic homeostasis disturbance in aquatic and mammalian $[18,30,50]$. Since ions are involved in a number of physiological processes, proper ion concentrations are crucial to maintain regular function of the heart and liver. Atrazine led to heart, liver and serum ionic disorders, induced structural alterations and dysfunction on heart and liver in quails. ATPases, which constitute a major category of ion transporters, are significantly suppressed by atrazine in aquatics and mammals [18, 30, 51, 52]. Our results showed the similar effects on ATPases activities in quails after atrazine exposure. In addition, SLCs gene levels were significantly decreased in heart and partially decreased (except SLC8A1 and SLC8A2) in liver. These results demonstrated that atrazine can induce ionic disorders by altering ATPases and contribute to organ dysfunction during intoxication.

There are many ionic pumps and ion channels involved in $\mathrm{Na}^{+}, \mathrm{K}^{+}$homeostasis. Among them the most important one in all living cells is $\mathrm{Na}^{+}-\mathrm{K}^{+}$-ATPase, which actively transport $\mathrm{K}^{+}$into and $\mathrm{Na}^{+}$out of the cells, responsible for the balance between $\mathrm{Na}^{+}, \mathrm{K}^{+}$intraand extracellular concentration, maintaining $\mathrm{Na}^{+}, \mathrm{K}^{+}$ serum levels [32]. Numerous studies determinated that atrazine-induced $\mathrm{Na}^{+}, \mathrm{K}^{+}$disorders are associated with the inhibition of $\mathrm{Na}^{+}-\mathrm{K}^{+}$-ATPase $[18,30,51,53,54]$. In



Figure 5: PCA of ionic homeostatic regulation after treated with atrazine. PCA score plot results comparing biochemical parameters of 4 treatment groups. a. PCA of ionic homeostatic regulation in heart; b. PCA of ionic homeostatic regulation in liver. 
the current study, atrazine decreased significantly the concentrations of cardiac, hepatic $\mathrm{K}^{+}$, which revealed that the decrease of cardiac and hepatic $\mathrm{K}^{+}$may be a response to the increase of $\mathrm{K}^{+}$outside the cardiomyocytes and hepatocytes via disturbing $\mathrm{Na}^{+}-\mathrm{K}^{+}$-ATPase on quails. The changes of contents of $\mathrm{K}^{+}$of experimental group in the liver were more obvious than heart's, suggesting that atrazine could disorder $\mathrm{K}^{+}$content directly via influencing $\mathrm{Na}^{+}-\mathrm{K}^{+}$-ATPase activities. Moreover, atrazine caused cardiac, hepatic, nephric dysfunction, activated renin-angiotensin-aldosterone system, boosted levels of aldosterone [55]. The role of aldosterone is to promote $\mathrm{K}^{+}$excretion and $\mathrm{Na}^{+}$reabsorption. Thus, the contents of $\mathrm{K}^{+}$in serum drop as well. The decreased $\mathrm{Na}^{+}-\mathrm{K}^{+}-$ ATPase activity causes retention of $\mathrm{Na}^{+}$in the cells. These results suggested that atrazine delivered cardiotoxicity and hepatotoxicity in quail via the decreased of $\mathrm{Na}^{+}-$ $\mathrm{K}^{+}$-ATPase activity and subunit transcription as well as disorders in $\mathrm{K}^{+}$levels (Figure 6).

Changes in $\mathrm{Ca}^{2+}$ are very important during signal transduction processes involved in cellular functions $[56,57]$. In cardiac myocytes, elevated cytosolic free $\mathrm{Ca}^{2+}$ required for muscle contraction should be removed rapidly to ensure relaxation; otherwise the overloading of $\mathrm{Ca}^{2+}$ activated a variety of $\mathrm{Ca}^{2+}$-dependent degradation enzymes, inducing arrhythmia and myocardial damage. In hepatocytes, CD38-mediated $\mathrm{Ca}^{2+}$ signaling contributes to angiotensin II-induced activation of hepatic stellate cells, inducing hepatic fibrosis [58]. Additionally, $\mathrm{Ca}^{2+}$ over loading stimulate mitochondrial damage, increase free radicals; free radical damage to the membrane, increased $\mathrm{Ca}^{2+}$ permeability, and then in turn promote $\mathrm{Ca}^{2+}$ overloading, induce tissues injury. Atrazine is considered to be undesirable because of its adverse effects on living organisms to induce $\mathrm{Ca}^{2+}$ release $[18,30,59,60]$. Atrazine exposure was accompanied by significant decrease in $\mathrm{Ca}^{2+}$-ATPases and disturbed $\mathrm{Ca}^{2+}$ homeostasis [59]. The overall increase in $\mathrm{Ca}^{2+}$ concentration in heart and liver of quails after atrazine exposure may disturb organ function in this study.

$\mathrm{NCX}$, as a bidirectional antiporter, is membrane transporters [61-63]; the ion-exchange process is electrogenic, with a stoichiometry of $3 \mathrm{Na}^{+}$for $1 \mathrm{Ca}^{2+}$ [64]. $\mathrm{NCKX}$, a $\mathrm{K}^{+}$-dependent $\mathrm{Na}^{+} / \mathrm{Ca}^{2+}$ exchanger, exchange $4 \mathrm{Na}^{+}$for $1 \mathrm{Ca}^{2+}$ and $1 \mathrm{~K}^{+}$[39]. $\mathrm{Na}^{+} / \mathrm{Ca}^{2+}$ exchangers (NCX, NCKX) use the $\mathrm{Na}^{+}$electrochemical gradient across the plasma membrane to extrude intracellular $\mathrm{Ca}^{2+}$ and maintain $\mathrm{Ca}^{2+}$ homeostasis. NCXs and NCKXs are encoded by SLCs [61, 65-68]. In the present study, we also found that SLCs and $\mathrm{Ca}^{2+}$-ATPase associated subunits transcriptions were significantly decreased by atrazine, which may be responsible for the overloading

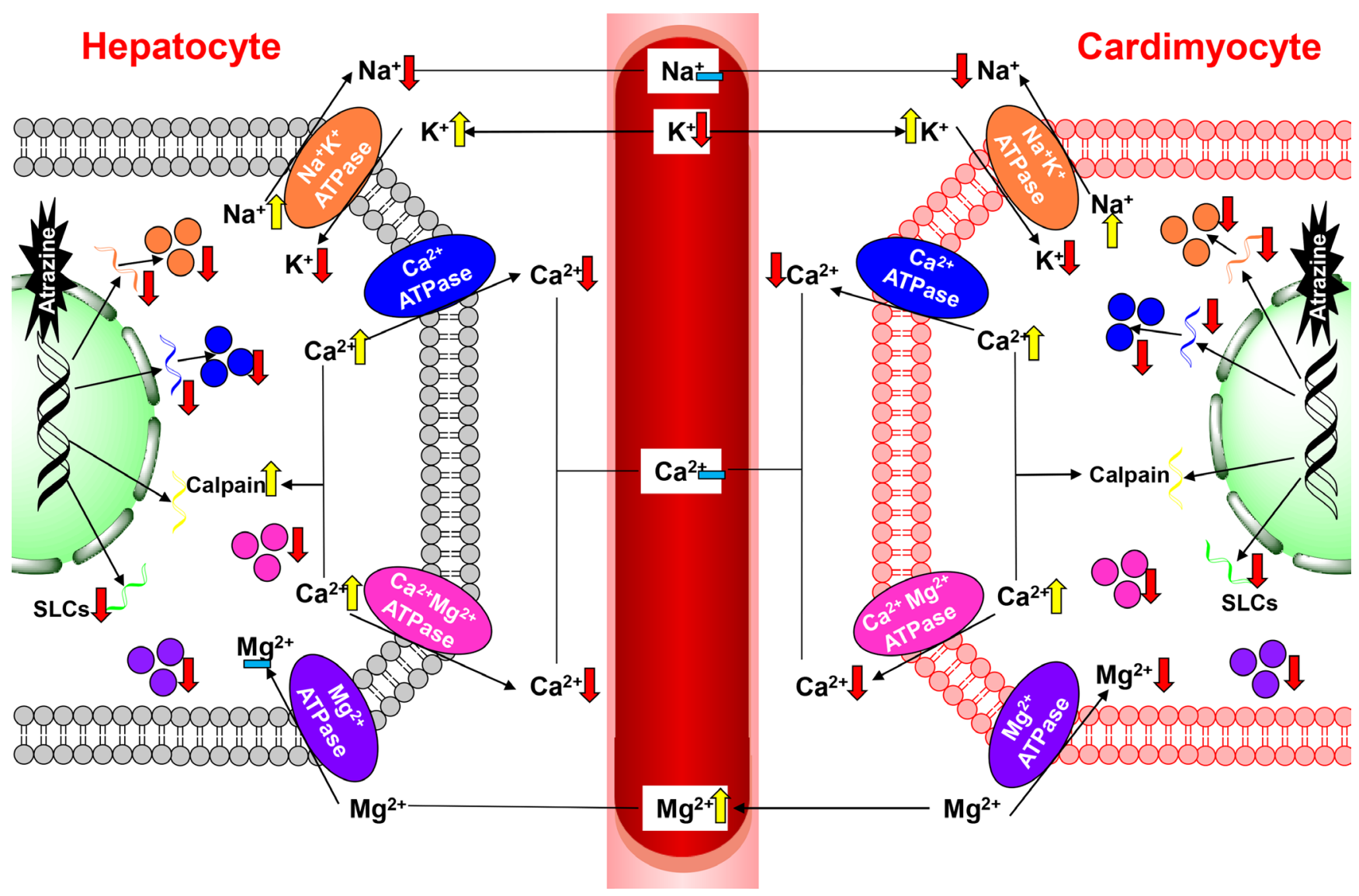

Figure 6: The pathway of atrazine induced ionic disorder in the heart, liver and serum. 
of $\mathrm{Ca}^{2+}$. Moreover, the retention of $\mathrm{Na}^{+}$in the cells leads to the inhibition of the NCXs expression and the $\mathrm{Ca}^{2+}$ overload in the cells. The further overloading of $\mathrm{Ca}^{2+}$, the increase of $\mathrm{Na}^{+}$by $\mathrm{Na}^{+}-\mathrm{K}^{+}$-ATPase were relieved by NCX. Thus, the changes of $\mathrm{Na}^{+}$contents were not obvious compared with the $\mathrm{K}^{+}$contents. As a consequence of $\mathrm{Ca}^{2+}$ influx by atrazine, the transcription of calpain is partially activated. Although the change of the activity of $\mathrm{Ca}^{2+}$ ATPase was extremely obvious in liver, the changes of the NCXs expression were more extremely obvious in heart. Additionally, Unlike $\mathrm{Na}^{+}$channels, $\mathrm{Ca}^{2+}$ channels are also regulated by neurotransmitters. Several studies had reported that atrazine could activate cAMP [69-71] and then activate L-type $\mathrm{Ca}^{2+}$ channel, inducing the influx of $\mathrm{Ca}^{2+}$. However, the excretion of $\mathrm{Ca}^{2+}$ is inhibited by $\mathrm{Ca}^{2+}$-ATPase. The overloading of $\mathrm{Ca}^{2+}$ in the hepatocytes can be discharged to the bile by the activation of cAMP. Thus, the changes of the $\mathrm{Ca}^{2+}$ content were not obvious in liver compared with in heart. These findings emphasize the view that the decreased $\mathrm{Ca}^{2+}$-ATPase activity may contribute to the disturb of intracellular $\mathrm{Ca}^{2+}$ homeostasis by increasing $\mathrm{Ca}^{2+}$-ATPase associated subunits and SLCs mRNA levels, leading the organ dysfunction (Figure 6).

Atrazine-induced malfunction in tissues is associated with $\mathrm{Mg}^{2+}$ imbalance $[72,73] . \mathrm{Mg}^{2+}$ is a cofactor for several enzymes such as $\mathrm{Na}^{+}-\mathrm{K}^{+}$-ATPase and $\mathrm{Ca}^{2+}$-ATPase that maintain the ionic balance [74]. Both pumps are $\mathrm{Mg}^{2+}$ dependent, and $\mathrm{Mg}^{2+}$ deficiency can impair ATPases functions $[75,76]$. Conversely, $\mathrm{Mg}^{2+}$ deficiency leading to damage to ATPases [77]. Additionally, the recent research raise the issue of $\mathrm{Mg}^{2+}$ is a physiologically important regulator of $\mathrm{Ca}^{2+}$ channel function [78]. In the present study, atrazine exposure caused increase of the $\mathrm{Ca}^{2+} / \mathrm{Mg}^{2+}$ ratio thus eliciting ionic imbalance, inducing the ATPases disorder, and disrupting the function of heart and liver. Moreover, atrazine disturbed the $\mathrm{Mg}^{2+}$ balance and organ function on quails via decreasing the $\mathrm{Mg}^{2+}$-ATPase and $\mathrm{Ca}^{2+}-\mathrm{Mg}^{2+}$-ATPase.

In conclusion, atrazine induced cardiac and hepatic damage via causing the ionic disorder, triggering the transcription of the ion transporters and leading the histopathological and functional alternations in the heart and liver of quails. However, our study demonstrated atrazine significantly induced the ionic disorder in the organ via modulating the ATPases activities and disturbing the transcription of the ion transporters (Figure 6). Therefore, it is hypothesized that triggering ionic disorder and disruption of ATPases is the novel mechanism of atrazine-induced toxicity. This study provides novel insights into the ionic disorder and toxicological responses to atrazine.

\section{MATERIALS AND METHODS}

\section{Animals and treatments}

Male quails (Coturnix C. coturnix) aged 18 days and weighted $89.04 \pm 3.66 \mathrm{~g}$ were purchased from Wan Jia farm in Harbin, China. Chemical atrazine $\left(\mathrm{C}_{8} \mathrm{H}_{14} \mathrm{ClN}_{5}\right.$, CAS: 1912-24-9) was purchased from Zhonghe Chemical Limited Company (Binzhou, China). Birds were housed in cages in an environmentally controlled room (temperature $26 \pm 2 \square$ and humidity $50 \pm 15 \%$ ). Temperature and relative humidity were monitored daily. Feed and water were offered ad libitum during the experiment. After one week acclimation, the quails were randomly divided into four groups (Table 1). Birds were administered atrazine once a day orally by gavage for 45 days. The gavage concentration of atrazine was $0,50,250,500 \mathrm{mg} / \mathrm{kg}$ bodyweight for each group. Usually effects appear late after exposure due to the time needed to modify the compensation mechanisms that maintain the homeostasis of organisms. To cover these long-term effects, possible alterations in the experimental animals were monitored at 45 days after the beginning of treatment. All of this makes the conditions used in the present work closer to realistic field situations [45].

The current ecological risk assessment for atrazine in avian species established by the USEPA reports a dietary LOAEL (lowest observable adverse effect level) of $675 \mathrm{mg} / \mathrm{kg}$ in the northern bobwhite quail. In this study, all the experiments conducted in animals were in accordance with the guidance of ethical committee for research on laboratory animals.

At the end of the experiment, the quails were weighed. Then, the birds were fasted before the day of sacrifice, and their heart and liver were carefully dissected out and weighed, then storing at $-80 \square$ for assays. And the organ coefficient is obtained by the ratio of organ weight to body weight. The blood was collected from the heart of each bird and centrifuged at $3000 \mathrm{rpm}$ for $10 \mathrm{~min}$ to obtain the serum. The serum were stored at $-80 \square$ for assays.

\section{Determination of biochemical parameters}

Blood samples were used to investigate changes in the serum enzymes and concentration of ions considered to be biochemical indicators of hepatic and myocardial enzyme. Serum $\mathrm{Na}^{+}, \mathrm{K}^{+}, \mathrm{Ca}^{2+}, \mathrm{Mg}^{2+}, \mathrm{Cl}^{-}$ concentrations and the activities of creatine kinase (CK), lactate dehydrogenase (LDH), choline esterase (CHE), glutamyltranspeptidase (GGT) were measured. The activities or contents of biochemical parameters were detected using the detection kits (Jiangsu SINNOWA Medical Technology Company, China) by a biochemical auto-analyzer. 


\section{Histological and ultrastructural observations}

Cardiac and hepatic specimens were fixed in 10\% buffered neutral formalin and were processed for paraffin wax sectioning. Sections of about $5 \mu \mathrm{m}$ thickness were stained with hematoxylin and eosin for light microscopy.

\section{ATPase activity assays}

The activities of $\mathrm{Na}^{+}-\mathrm{K}^{+}$-ATPase, $\mathrm{Ca}^{2+}$-ATPase, $\mathrm{Mg}^{2+}$-ATPase and $\mathrm{Ca}^{2+}-\mathrm{Mg}^{2+}$-ATPase were determined using the appropriate assay kits (Nanjing Jiancheng Bioengineering Institute, China) according to the manufacturer's instructions using $10 \%$ tissue homogenates $[18,30]$.

\section{RNA purification and Quantitative real-time PCR}

Total mRNA was extracted from hypothalamo, pituitary and ovary using RNAout reagent (Beijing Tiandz, Inc. China), according to the manufacturer's instructions. First cDNA strand was synthesized using TransScript All-in-One First-Strand cDNA Synthesis SuperMix for quantitative real-time PCR (qRT-PCR) (One-Step gDNA Removal) (Beijing TransGen Biotech Co. Ltd., China). The primers for real-time amplification of relative cDNAs were designed using Oligo 7.22 Software (Molecular Biology Insights, Cascade, CO) based on the deposited sequences in GenBank and primers used are given in Table S1 of the Supplementary Material. qRT-PCR was conducted using LightCycler ${ }^{\circledR} 480$ Real-Time PCR System (Roche, $\mathrm{CH}$ ). Triplicate samples were assessed for each gene of interest, and $\beta$-actin was used as a control gene. Relative expression levels were determined by the $2^{-\Delta \Delta \mathrm{Ct}}$ method [79], the results were normalized to the mean of ACTB.

\section{Statistical analysis}

The data was analyzed with GraphPad Prism 5.1 (GraphPad Software Inc., USA) and SPSS 19.0 software (SPSS Inc., USA). Statistical analyses were performed using one-way ANOVA followed by Tukey's post hoc pairwise comparison. Asterisks $(*)$ indicate statistically significant differences from the control group, $* P<0.05$, $* * P<0.01$ and $* * * P<0.001$. Ranking of genes by degree of differential expression was analyzed with a heat map using the $\mathrm{R}$ Programming Language version 3.2.1. In addition, Principal component analysis (PCA) was used as an effective tool for simplifying the information from inter-correlated variables through linear transformation of the original variables into a few principal components. PCA was performed in this work to define the most important parameters, which could be used as key factors for individual variations using the same software. The observed relationships among the parameters were confirmed and quantified according to a Spearman's test. All data was presented as mean \pm standard deviation (SD). In addition, Chem Draw Pro (version 15.0) was used for drawing pictures.

\section{ACKNOWLEDGMENTS}

This work was supported by China New Century Excellent Talents in University (No. NECT-120702), National Natural Science Foundation of China (No. 31572586) and Academic Backbone Project of Northeast Agricultural University (No. 15XG16). We also acknowledge the valuable help provided by Prof. ShiWen $\mathrm{Xu}$ in Northeast Agricultural University and all of the workers involved.

\section{CONFLICTS OF INTEREST}

The authors declare that there are no conflicts of interests.

\section{GRANT SUPPORT}

China New Century Excellent Talents in University (No. NECT-1207-02);

National Natural Science Foundation of China (No. 31572586);

Academic Backbone Project of Northeast Agricultural University (No. 15XG16).

\section{REFERENCES}

1. Stayner LT, Almberg K, Jones R, Graber J, Pedersen M and Turyk M. Atrazine and nitrate in drinking water and the risk of preterm delivery and low birth weight in four Midwestern states. Environ Res. 2016; 152:294-303.

2. Loos R, Locoro G, Comero S, Contini S, Schwesig D, Werres F, Balsaa P, Gans O, Weiss S, Blaha L, Bolchi M and Gawlik BM. Pan-European survey on the occurrence of selected polar organic persistent pollutants in ground water. Water Res. 2010; 44(14):4115-4126.

3. Lenkowski JR, Reed JM, Deininger L and McLaughlin KA. Perturbation of organogenesis by the herbicide atrazine in the amphibian Xenopus laevis. Environ Health Perspect. 2008; 116(2):223-230.

4. Capel PD and Larson SJ. Effect of scale on the behavior of atrazine in surface waters. Environ Sci Technol. 2001; 35(4):648-657.

5. Nodler K, Licha T and Voutsa D. Twenty years later-atrazine concentrations in selected coastal waters of the Mediterranean and the Baltic Sea. Mar Pollut Bull. 2013; 
70(1-2):112-118.

6. Juhel G, Bayen S, Goh C, Lee WK and Kelly BC. Use of a suite of biomarkers to assess the effects of carbamazepine, bisphenol A, atrazine, and their mixtures on green mussels, Perna viridis. Environ Toxicol Chem. 2016.

7. Hussain R, Mahmood F, Khan MZ, Khan A and Muhammad F. Pathological and genotoxic effects of atrazine in male Japanese quail (Coturnix japonica). Ecotoxicology. 2011; 20(1):1-8.

8. Ottinger MA, Lavoie ET, Thompson N, Bohannon M, Dean $\mathrm{K}$ and Quinn MJ, Jr. Is the gonadotropin releasing hormone system vulnerable to endocrine disruption in birds? Gen Comp Endocrinol. 2009; 163(1-2):104-108.

9. Wilhelms KW, Cutler SA, Proudman JA, Carsia RV, Anderson LL and Scanes CG. Lack of effects of atrazine on estrogen-responsive organs and circulating hormone concentrations in sexually immature female Japanese quail (Coturnix coturnix japonica). Chemosphere. 2006; 65(4):674-681.

10. Wilhelms KW, Cutler SA, Proudman JA, Anderson LL and Scanes CG. Atrazine and the hypothalamo-pituitarygonadal axis in sexually maturing precocial birds: studies in male Japanese quail. Toxicol Sci. 2005; 86(1):152-160.

11. de la Casa-Resino I, Valdehita A, Soler F, Navas JM and Perez-Lopez M. Endocrine disruption caused by oral administration of atrazine in European quail (Coturnix coturnix coturnix). Comp Biochem Physiol C Toxicol Pharmacol. 2012; 156(3-4):159-165.

12. Qin L, Du ZH, Zhu SY, Li XN, Li N, Guo JA, Li JL and Zhang Y. Atrazine triggers developmental abnormality of ovary and oviduct in quails (Coturnix Coturnix coturnix) via disruption of hypothalamo-pituitary-ovarian axis. Environ Pollut. 2015; 207:299-307.

13. Xing H, Wang Z, Gao X, Chen D, Wang L, Li S and Xu S. Atrazine and chlorpyrifos exposure induces liver autophagic response in common carp. Ecotoxicol Environ Saf. 2015; 113:52-58.

14. Xia J, Lin J, Zhu SY, Du ZH, Guo JA, Han ZX, Li JL and Zhang Y. Lycopene protects against atrazine-induced hepatotoxicity through modifications of cytochrome P450 enzyme system in microsomes. Exp Toxicol Pathol. 2016; 68(4):223-231.

15. Campos-Pereira FD, Oliveira CA, Pigoso AA, SilvaZacarin EC, Barbieri R, Spatti EF, Marin-Morales MA and Severi-Aguiar GD. Early cytotoxic and genotoxic effects of atrazine on Wistar rat liver: a morphological, immunohistochemical, biochemical, and molecular study. Ecotoxicol Environ Saf. 2012; 78:170-177.

16. Graziano N, McGuire MJ, Roberson A, Adams C, Jiang $\mathrm{H}$ and Blute N. 2004 National Atrazine Occurrence Monitoring Program using the Abraxis ELISA method. Environ Sci Technol. 2006; 40(4):1163-1171.

17. Wiegand C, Krause E, Steinberg C and Pflugmacher S. Toxicokinetics of atrazine in embryos of the zebrafish
(Danio rerio). Ecotoxicol Environ Saf. 2001; 49(3):199205.

18. Lin J, Li HX, Xia J, Li XN, Jiang XQ, Zhu SY, Ge J and Li JL. The chemopreventive potential of lycopene against atrazine-induced cardiotoxicity: modulation of ionic homeostasis. Sci Rep. 2016; 6:24855.

19. Adeyemi JA, da Cunha Martins-Junior A and Barbosa F, Jr. Teratogenicity, genotoxicity and oxidative stress in zebrafish embryos (Danio rerio) co-exposed to arsenic and atrazine. Comp Biochem Physiol C Toxicol Pharmacol. 2015; 172-173:7-12.

20. Glisic B, Hrubik J, Fa S, Dopudj N, Kovacevic R and Andric N. Transcriptional profiles of glutathione-STransferase isoforms, Cyp, and AOE genes in atrazineexposed zebrafish embryos. Environ Toxicol. 2016; 31(2):233-244.

21. Nwani CD, Ifo CT, Nwamba HO, Ejere VC, Onyishi GC, Oluah SN, Ikwuagwu OE and Odo GE. Oxidative stress and biochemical responses in the tissues of African catfish Clarias gariepinus juvenile following exposure to primextra herbicide. Drug Chem Toxicol. 2015; 38(3):278-285.

22. Chen D, Zhang Z, Yao H, Liang Y, Xing H and Xu S. Effects of atrazine and chlorpyrifos on oxidative stressinduced autophagy in the immune organs of common carp (Cyprinus carpio L.). Fish Shellfish Immunol. 2015; 44(1):12-20.

23. Zhao F, Li K, Zhao L, Liu J, Suo Q, Zhao J, Wang H and Zhao S. Effect of Nrf2 on rat ovarian tissues against atrazine-induced anti-oxidative response. Int J Clin Exp Pathol. 2014; 7(6):2780-2789.

24. Abass MA, Elkhateeb SA, Abd El-Baset SA, Kattaia AA, Mohamed EM and Atteia HH. Lycopene ameliorates atrazine-induced oxidative damage in adrenal cortex of male rats by activation of the Nrf2/HO-1 pathway. Environ Sci Pollut Res Int. 2016; 23(15):15262-15274.

25. Abarikwu SO and Farombi EO. Atrazine induces apoptosis of SH-SY5Y human neuroblastoma cells via the regulation of Bax/Bcl-2 ratio and caspase-3-dependent pathway. Pestic Biochem Physiol. 2015; 118:90-98.

26. Singh M, Sandhir R and Kiran R. Atrazine-induced alterations in rat erythrocyte membranes: ameliorating effect of vitamin E. J Biochem Mol Toxicol. 2008; 22(5):363-369.

27. Singh M, Kaur P, Sandhir R and Kiran R. Protective effects of vitamin $\mathrm{E}$ against atrazine-induced genotoxicity in rats. Mutat Res. 2008; 654(2):145-149.

28. Sagarkar S, Gandhi D, Devi SS, Sakharkar A and Kapley A. Atrazine exposure causes mitochondrial toxicity in liver and muscle cell lines. Indian J Pharmacol. 2016; 48(2):200-207.

29. Ribas G, Frenzilli G, Barale R and Marcos R. Herbicideinduced DNA damage in human lymphocytes evaluated by the single-cell gel electrophoresis (SCGE) assay. Mutat Res. 1995; 344(1-2):41-54.

30. Lin J, Zhao HS, Xiang LR, Xia J, Wang LL, Li XN, Li JL and Zhang Y. Lycopene protects against atrazine-induced 
hepatic ionic homeostasis disturbance by modulating iontransporting ATPases. J Nutr Biochem. 2016; 27:249-256.

31. Feng $M$, Wang $X$, Wang $C$, Qin L, Wei Z and Wang Z. Antioxidant status and $\mathrm{Na}(+), \mathrm{K}(+)$-ATPase activity in freshwater fish Carassius auratus exposed to different combustion products of Nafion 117 membrane: an integrated biomarker approach. Environ Sci Pollut Res Int. 2015; 22(5):3408-3418.

32. Fijorek K, Puskulluoglu M, Tomaszewska D, Tomaszewski R, Glinka A and Polak S. Serum potassium, sodium and calcium levels in healthy individuals - literature review and data analysis. Folia Med Cracov. 2014; 54(1):53-70.

33. Kawasaki R, Machado C, Reinoehl J, Fromm B, Baga JJ, Steinman RT and Lehmann MH. Increased propensity of women to develop torsades de pointes during complete heart block. J Cardiovasc Electrophysiol. 1995; 6(11):10321038.

34. Wang XD. Lycopene metabolism and its biological significance. Am J Clin Nutr. 2012; 96(5):1214S-1222S.

35. Uner N, Oruc E and Sevgiler Y. Oxidative stress-related and ATPase effects of etoxazole in different tissues of Oreochromisniloticus. Environ Toxicol Pharmacol. 2005; 20(1):99-106.

36. Scheiner-Bobis G. The sodium pump. Its molecular properties and mechanics of ion transport. Eur J Biochem. 2002; 269(10):2424-2433.

37. Ozcan Oruc E, Uner $\mathrm{N}$ and Tamer L. Comparison of $\mathrm{Na}(+)$ $\mathrm{K}(+)$-ATPase activities and malondialdehyde contents in liver tissue for three fish species exposed to azinphosmethyl. Bull Environ Contam Toxicol. 2002; 69(2):271-277.

38. Paulino MG, Sakuragui MM and Fernandes MN. Effects of atrazine on the gill cells and ionic balance in a neotropical fish, Prochilodus lineatus. Chemosphere. 2012; 86(1):1-7.

39. Lytton J. Na+/Ca2+ exchangers: three mammalian gene families control Ca2+ transport. Biochem J. 2007; 406(3):365-382.

40. Quednau BD, Nicoll DA and Philipson KD. The sodium/ calcium exchanger family-SLC8. Pflugers Arch. 2004; 447(5):543-548.

41. Schnetkamp PP. The SLC24 gene family of $\mathrm{Na}(+) / \mathrm{Ca}(2)$ $(+)-\mathrm{K}(+)$ exchangers: from sight and smell to memory consolidation and skin pigmentation. Mol Aspects Med. 2013; 34(2-3):455-464.

42. Cosselman KE, Navas-Acien A and Kaufman JD. Environmental factors in cardiovascular disease. Nat Rev Cardiol. 2015; 12(11):627-642.

43. Santa Maria C, Moreno J and Lopez-Campos JL. Hepatotoxicity induced by the herbicide atrazine in the rat. J Appl Toxicol. 1987; 7(6):373-378.

44. Gojmerac T, Kartal B, Zuric M, Curic S and Mitak M. Serum biochemical and histopathological changes related to the hepatic function in pigs following atrazine treatment. J Appl Toxicol. 1995; 15(3):233-236.

45. de la Casa-Resino I, Hernandez-Moreno D, Navas JM, Soler
F and Perez-Lopez M. Non-destructive multibiomarker approach in European quail (Coturnix coturnix coturnix) exposed to the herbicide atrazine. Arch Environ Contam Toxicol. 2013; 65(3):567-574.

46. du Preez HH and van Vuren JH. Bioconcentration of atrazine in the banded tilapia, Tilapia sparrmanii. Comp Biochem Physiol C. 1992; 101(3):651-655.

47. Lin Z, Fisher JW, Ross MK and Filipov NM. A physiologically based pharmacokinetic model for atrazine and its main metabolites in the adult male C57BL/6 mouse. Toxicol Appl Pharmacol. 2011; 251(1):16-31.

48. Ross MK, Jones TL and Filipov NM. Disposition of the herbicide 2-chloro-4-(ethylamino)-6-(isopropylamino)s-triazine (Atrazine) and its major metabolites in mice: a liquid chromatography/mass spectrometry analysis of urine, plasma, and tissue levels. Drug Metab Dispos. 2009; 37(4):776-786.

49. Reindl AR, Falkowska L and Grajewska A. Chlorinated herbicides in fish, birds and mammals in the Baltic Sea. Water Air Soil Pollut. 2015; 226(8):276.

50. Nieves-Puigdoller K, Bjornsson BT and McCormick SD. Effects of hexazinone and atrazine on the physiology and endocrinology of smolt development in Atlantic salmon. Aquat Toxicol. 2007; 84(1):27-37.

51. Nascimento CR, Souza MM and Martinez CB. Copper and the herbicide atrazine impair the stress response of the freshwater fish Prochilodus lineatus. Comp Biochem Physiol C Toxicol Pharmacol. 2012; 155(3):456-461.

52. Bhatti JS, Sidhu IP and Bhatti GK. Ameliorative action of melatonin on oxidative damage induced by atrazine toxicity in rat erythrocytes. Mol Cell Biochem. 2011; 353(1-2):139149.

53. Yang L, Zha J, Li W, Li Z and Wang Z. Atrazine affects kidney and adrenal hormones (AHs) related genes expressions of rare minnow (Gobiocypris rarus). Aquat Toxicol. 2010; 97(3):204-211.

54. Waring CP and Moore A. The effect of atrazine on Atlantic salmon (Salmo salar) smolts in fresh water and after sea water transfer. Aquat Toxicol. 2004; 66(1):93-104.

55. Rogers JM, Ellis-Hutchings RG, Grey BE, Zucker RM, Norwood J, Jr., Grace CE, Gordon CJ and Lau C. Elevated blood pressure in offspring of rats exposed to diverse chemicals during pregnancy. Toxicol Sci. 2014; 137(2):436-446.

56. Berridge MJ, Bootman MD and Roderick HL. Calcium signalling: dynamics, homeostasis and remodelling. Nat Rev Mol Cell Biol. 2003; 4(7):517-529.

57. Karlstad J, Sun Y and Singh BB. $\mathrm{Ca}(2+)$ signaling: an outlook on the characterization of $\mathrm{Ca}(2+)$ channels and their importance in cellular functions. Adv Exp Med Biol. 2012; 740:143-157.

58. Kim SY, Cho BH and Kim UH. CD38-mediated Ca2+ signaling contributes to angiotensin II-induced activation of hepatic stellate cells: attenuation of hepatic fibrosis by 
CD38 ablation. J Biol Chem. 2010; 285(1):576-582.

59. Singh M, Sandhir R and Kiran R. Alterations in $\mathrm{Ca} 2+$ homeostasis in rat erythrocytes with atrazine treatment: positive modulation by vitamin E. Mol Cell Biochem. 2010; 340(1-2):231-238.

60. Bonilla IM, Long VP, 3rd, Vargas-Pinto P, Wright P, Belevych A, Lou Q, Mowrey K, Yoo J, Binkley PF, Fedorov VV, Gyorke S, Janssen PM, Kilic A, Mohler PJ and Carnes CA. Calcium-activated potassium current modulates ventricular repolarization in chronic heart failure. PLoS One. 2014; 9(10):e108824.

61. Blaustein MP and Lederer WJ. Sodium/calcium exchange: its physiological implications. Physiol Rev. 1999; 79(3):763-854.

62. Philipson KD and Nicoll DA. Sodium-calcium exchange: a molecular perspective. Annu Rev Physiol. 2000; 62:111133.

63. DiPolo R and Beauge L. Sodium/calcium exchanger: influence of metabolic regulation on ion carrier interactions. Physiol Rev. 2006; 86(1):155-203.

64. Hilgemann DW, Nicoll DA and Philipson KD. Charge movement during $\mathrm{Na}+$ translocation by native and cloned cardiac $\mathrm{Na}+/ \mathrm{Ca} 2+$ exchanger. Nature. 1991; 352(6337):715718.

65. Nicoll DA, Longoni S and Philipson KD. Molecular cloning and functional expression of the cardiac sarcolemmal $\mathrm{Na}(+)-\mathrm{Ca} 2+$ exchanger. Science. 1990; 250(4980):562-565.

66. Lee SL, Yu AS and Lytton J. Tissue-specific expression of $\mathrm{Na}(+)-\mathrm{Ca} 2+$ exchanger isoforms. J Biol Chem. 1994; 269(21):14849-14852.

67. Nicoll DA, Quednau BD, Qui Z, Xia YR, Lusis AJ and Philipson KD. Cloning of a third mammalian $\mathrm{Na}+-\mathrm{Ca} 2+$ exchanger, NCX3. J Biol Chem. 1996; 271(40):2491424921.

68. Quednau BD, Nicoll DA and Philipson KD. Tissue specificity and alternative splicing of the $\mathrm{Na}+\mathrm{Ca} 2+$ exchanger isoforms NCX1, NCX2, and NCX3 in rat. Am J Physiol. 1997; 272(4 Pt 1):C1250-1261.

69. Karmaus AL and Zacharewski TR. Atrazine-Mediated Disruption of Steroidogenesis in BLTK1 Murine Leydig Cells. Toxicol Sci. 2015; 148(2):544-554.
70. Thueson LE, Emmons TR, Browning DL, Kreitinger JM, Shepherd DM and Wetzel SA. In vitro exposure to the herbicide atrazine inhibits $\mathrm{T}$ cell activation, proliferation, and cytokine production and significantly increases the frequency of Foxp3 + regulatory T cells. Toxicol Sci. 2015; 143(2):418-429.

71. Pogrmic-Majkic K, Samardzija D, Fa S, Hrubik J, Glisic B, Kaisarevic $\mathrm{S}$ and Andric N. Atrazine enhances progesterone production through activation of multiple signaling pathways in FSH-stimulated rat granulosa cells: evidence for premature luteinization. Biol Reprod. 2014; 91(5):124.

72. Chakraborti S, Chakraborti T, Mandal M, Mandal A, Das S and Ghosh S. Protective role of magnesium in cardiovascular diseases: a review. Mol Cell Biochem. 2002; 238(1-2):163-179.

73. Fuentes JC, Salmon AA and Silver MA. Acute and chronic oral magnesium supplementation: effects on endothelial function, exercise capacity, and quality of life in patients with symptomatic heart failure. Congest Heart Fail. 2006; 12(1):9-13.

74. Iezhitsa IN and Spasov AA. [Potassium magnesium homeostasis: physiology, pathophysiology, clinical consequences of deficiency and pharmacological correction]. Usp Fiziol Nauk. 2008; 39(1):23-41.

75. Mak IT, Komarov AM, Wagner TL, Stafford RE, Dickens $\mathrm{BF}$ and Weglicki WB. Enhanced NO production during $\mathrm{Mg}$ deficiency and its role in mediating red blood cell glutathione loss. Am J Physiol. 1996; 271(1 Pt 1):C385390.

76. Hans CP, Chaudhary DP and Bansal DD. Magnesium deficiency increases oxidative stress in rats. Indian J Exp Biol. 2002; 40(11):1275-1279.

77. Chaudhary DP, Boparai RK and Bansal DD. Implications of oxidative stress in high sucrose low magnesium diet fed rats. Eur J Nutr. 2007; 46(7):383-390.

78. Wang M, Tashiro M and Berlin JR. Regulation of L-type calcium current by intracellular magnesium in rat cardiac myocytes. J Physiol. 2004; 555(Pt 2):383-396.

79. Livak KJ and Schmittgen TD. Analysis of relative gene expression data using real-time quantitative PCR and the 2(-Delta Delta C(T)) Method. Methods. 2001; 25(4):402408 . 